\title{
It is a Scary and Dangerous World: A Content Analysis of Xinwen Lianbo's News Coverage of Foreign Affairs
}

\author{
By Zedan Xu* \& Andrew M. Clark
}

\begin{abstract}
The television program Xinwen Lianbo has been China's flagship state-run newscast since 1978. Today, even with competition from other options and a decline in interest from younger viewers, it still has an audience of over 130 million people making it the most-watched TV news program in China. This study uses a content analysis of foreign affairs stories in the newscast from 2012-2016 to determine how the world outside of China is framed in the newscast. Results show that through the topics covered the world is continuously framed as a scary and dangerous place. The research in this study lines up with prior research that suggests that exposure to negative news, particularly news replete with disasters, terrorism, crime, and scandals, perpetuates fear among the Chinese audience. Of particular note is that many smaller and less powerful countries occupied the newscast more frequently than the "known" countries such as the United States. Coverage of war and conflict in the Middle East was important in the construction of the chaotic and dangerous outside world frame. By casting foreign countries in a negative light, and China and its leaders in a very positive light, the domestic audience is persuaded that China is one of the safest and most orderly countries in the world. This study shines a spotlight on China's strategies for domestic propaganda and ideological control, indicating the Chinese Communist Party's efforts to effectively and imperceptibly strengthen the efficacy of the propaganda system.
\end{abstract}

Keywords: China, broadcast news, foreign affairs, framing, Xinwen Lianbo.

\section{Introduction}

Since its creation in 1978, Xinwen Lianbo has been China's flagship state-run newscast. In its prime, this daily news television program produced by China Central Television (CCTV), garnered up to 400 million viewers each day (Zhu $\&$ Berry, 2009). Today, even with competition from other options and a decline in interest from younger viewers, it still has an audience of over 130 million people, making it the most-watched TV news program in China ("No news is bad news," 2016; Sterling, 2009; People's Daily, 2014). Xinwen Lianbo airs nightly at 7:00 p.m., and is broadcast simultaneously by most of the terrestrial television channels throughout China. Xinwen Lianbo is "the most high-profile television news program in China as government regulations have made it virtually the only TV news program available around dinner time for most families" (Huang, 2015, p. 48). As Sun and Chio (2012) note, "almost all regional television stations across China broadcast Xinwen Lianbo because they cannot receive a signal from any other source during this time period leaving them no choice but to transmit the program" (p. 105). Simulcasting this program is very much a part of the political mission or propaganda strategy of the Chinese

*International Relations, University of Chicago, USA.

${ }^{\dagger}$ Associate Professor, Department of Communication, University of Texas at Arlington, USA. 
government in order to reach both urban and rural audiences across the country.

From its inception, Xinwen Lianbo has been institutionally and ideologically incorporated into the Chinese government's media system as a propaganda mouthpiece (Sterling, 2009). In an article looking at possible changes in the newscast, Huang (2014) quoted some viewers who noted "the news content, the order of news item and even the rhetoric in each report are decided by party officials," [and] "What they do is simply sit there and utter from the pre-censored script" (p. 1).

An article in The Economist provided more insight into the role of the program and its structure. It states that "Xinwen Lianbo has chronicled the country's extraordinary metamorphosis with almost unremitting leadenness since it was first aired in 1978" ("No news is bad news," 2016, p. 1). In terms of overall format, the same theme music has been used for nearly 30 years, although, as the author in The Economist notes, the orchestra has improved over time.

Even though it has been in existence for forty years, the structure of the content, and its propagandistic philosophy has changed little over the years. There is no indication that the stories featured are chosen for anything but its political value in bolstering the Communist Party. The formulaic nature of the programming has remained constant over time. There are three programming blocks. In Block A, now, as when the program started, reports feature Chinese leaders, no matter how trivial their activities. Block B show how happy and healthy Chinese people are, and Block $\mathrm{C}$, the focus of this article, shows how chaotic the rest of the world is. "A typical programme (sic) in the 1980s highlighted the development of a self-opening umbrella and a contest in which happy only children (China had recently introduced a one-child-per-couple policy) performed household chores. Today the backdrop is just more high-tech. Scenes of bullettrains and microchip makers have replaced those of dreary state-owned factories" ("No news is bad news," 2016, p. 1).

The news narrative and content, the order of news items and even the rhetoric in each report are tightly controlled and decided by the Communist party officials. The newscast is translated into eight minority languages, just to be sure its message is understood by as many people as possible ("No news is bad news," 2016).

When the newscast began in 1978, it usually featured a male and female anchor "chosen for their standard Mandarin pronunciation and stolid demeanor" ("No news is bad news," 2016, p. 1). There has been relatively little turnover in anchors. Li Ruiying and Zhang Hongmin anchored the newscast beginning in the late 1980s until 2014, when both were in their 50s and it was announced they would be stepping down (Huang, 2014). They were replaced by:

younger, more glamorous presenters (though they still need official permission to change their hairstyles). To make broadcasts seem newsier, banks of TV screens flicker in what appears to be a newsroom behind. But live reports are rare; they create too big a risk of something embarrassing making it to air ("No news is bad news," 2016, p. 1). 
In talking about his philosophy of journalism and journalists, China's President Xi Jingping stated:

They (journalists and editors) should enhance their awareness to align their ideology, political thinking and deeds to those of the CPC (Central Committee of the Communist Party of China) Central Committee and help fashion the Party's theories and policies into conscious action by the general public while providing spiritual enrichment to the people ("China's Xi," 2016, p. 1).

Xinwen Lianbo truly is the media mouth of the Chinese government propaganda apparatus, a newscast that is more propaganda than a real news program (Chang \& Chen, 2000). Huang (2014) notes that there has been much criticism over the rigidity of the newscast's format over the years (party news, domestic news, and international news) and the obvious agenda that the newscast has. Young people no longer find it so appealing, and there is now more competition from other programming. Cody (2007) notes that the Internet offers some uncensored news. Zhou Xiapou, (cited in Cody 2007) says "the main viewers are China's legions of government and party officials, particularly in the provinces, and businessmen who want to keep up with the policies and attitudes that will affect their ability to make money" (p. 2). The lead author of this article recalls when he was a student, "students were organized to watch Xinwen Lianbo at 7:00 p.m. in class to get to familiarize with the current political affairs, both domestic and foreign. Part of the Politics exam would test our knowledge of the "current affairs (时事要闻)." Honestly, students do not have to get the news from Xinwen Lianbo. They can get it from People's Daily as well. But we knew that if something got onto Xinwen Lianbo, that must be very important and would be likely to be tested. All the answers to the "current affairs" part could be found on Xinwen Lianbo, this is for sure."

Young people do not find the newscast appealing because of the rigid and traditional style. Huang (2015) states that "The use of archaic and stilted prose glorifying the government" (p. 420) has led media scholars in China call it a performance, or a form of theater passed off as reality. "Despite this, the state orders almost all provincial TV stations in the country to simulcast Xinwen Lianbo at 7 p.m. every evening" (p. 420). The program does have its defenders. A Chinese telecom executive received some criticism after being dismissive of those who do not watch Xinwen Lianbo. He said that he watches the newscast with his daughters to catch up on Chinese politics and economic news ("Chinese Telecom," 2018).

As part of the propaganda apparatus, the news program reflects official positions of the Chinese Communist Party on a wide range of issues. Usually the news program is used as a medium for the state to broadcast official government announcements and the nation's top leaders' meetings with international dignitaries, as well as major social, economic and policy issues. However, as will be shown later, the coverage of foreign affairs by Xinwen Lianbo is used to frame the rest of the world as chaotic and dangerous, in clear contrast to how China and its leaders are portrayed. 


\section{Literature Review}

\section{Xinwen Lianbo}

Research on Xinwen Lianbo has focused on its use as a propaganda tool (Huang, 2015), as part of how television news in China has changed over the years within the context of political reform (Chang \& Ren, 2015), and as part of a study on the influence and rise of television anchors in China (Pugsley \& Gao, 2007). Scholars in disciplines such as linguistics (Liu, 2009; Liu, Hudson, \& Feng, 2009) have examined Xinwen Lianbo content and its influence on speech and language in various populations in China. In general, the research has not examined how the news program frames the public's perceptions of China and its relations with foreign countries. As the main source of political and social information, it is important to understand this aspect of the program, and how Xinwen Lianbo may shape the Chinese public's conceptions of international events.

Two studies in particular on Xinwen Lianbo have delved into how Xinwen Lianbo constructs a mediated reality and presents an impartial and balanced summary of significant events from particular points of view and gradually changed public perceptions of foreign nations. Chang and Ren (2015) showed how the content of the TV news program, served as a constructed social reality that shaped the audience's perception of international affairs. They suggest that Xinwen Lianbo serves as a symbolic political ritual in China, and argue that the news program serves as an ideological tool for the ruling party in hopes of gathering citizens into an "imagined community" of the nation. Chang, Wang, and Chen (2002) conducted a content analysis of the foreign news broadcasted on China Central Television between 1992 to 1998, and suggests that the coverage of foreign countries was primarily associated with social unrest, disasters and accidents. This study offers insights into measuring Xinwen Lianbo's capacity to influence the audience by constructing a biased social reality, but the data they used to approach their research problems was gathered in the mid to late 1990s. China's media landscape has changed dramatically during the past decades. Thus, new attempts should be made to illuminate what is happening in recent years.

Understanding the nature of international news coverage by the news media, particularly a large state-run agency is of great importance when considering its effect on the population. Television news programs serve as an important source of information for Chinese about events that occur around the world every day, particularly as many will never experience life outside of China for themselves. Xinwen Lianbo also clearly serves as a propaganda tool of the Chinese government.

\section{Propaganda}

A news program such as Xinwen Lianbo is what Jowett and O'Donnell (2006) consider a form of "white propaganda;" that is "it comes from a source that is identified correctly, and the information in the message tends to be accurate" (p. 
16). White propaganda, as with all propaganda has a specific purpose. Szanto (1978) notes that it is important to have an understanding of the context in which information is created. Information is never created in a vacuum, but is the product of a process from the time it is gathered, to the editing of the content, and the delivery to an intended audience with a specific end in mind. With white propaganda, "the information is presented in a manner that attempts to convince the audience that the sender is the 'good guy' with the best ideas and political ideology" (Jowett \& O’Donnell, 2006, p. 16).

Huang (2015) uses the term "soft propaganda" (p. 435) to describe Xinwen Lianbo. The newscast from Huang's perspective is less about indoctrination, and more about demonstrating control and power. "Propaganda is often not used for indoctrination, but rather to signal the government's strength in maintaining social control and political order" (p. 420).

Whether for indoctrination or as a demonstration of power, it is clear that Xinwen Lianbo is being used as part of a comprehensive propagandistic effort. When information about the world outside of China is presented, the information is framed in stark contrast to what is presented about China, its people and its leaders.

\section{Framing}

Framing theory was put forward by Goffman (1974) where he theorized that people's perceptions are guided by two classes of primary frameworks (or schemata): namely natural frameworks and social frameworks. Goffman's work reveals how frames classify phenomena, allowing the user to organize complex phenomena into coherent, understandable categories.

Following Goffman, Tuchman (1978) argues that as the "gate keepers," editors and reporters of the newsrooms selected the "newsworthy" events and issues and presented to the public. In this process, the news is translated to social reality and social knowledge, and afterwards news organizations shape and circulate such knowledge (Tuchman, 1978). Focusing on how media draw the public's eye to specific topics, framing analysis is a constructivist approach to examine how news discourse shapes and constructs people's perceptions of realities. Communication scholars have illustrated that frames function as cognitive shortcuts to help people interpret the world. In other words, by reducing the complexity of the world, media frames thereby render it comprehensible and meaningful.

Over the past decades, an impressive body of literature has contributed to the understanding of frames in the media studies (e.g., Entman, 1993, 2007; Terkildsen \& Schnell, 1997; Scheufele, 1999; Scheufle \& Tewksbury, 2007; Tierney, 2006; Matthes \& Kohring, 2008; Tewksbury \& Scheufele, 2009; Olausson, 2009). As noted in the studies, the frame of a news story is how it is presented to the viewers. News frames serve to influence the choices people make about how to process that information and structure message meaning. Gamson and Modigliani (1989) argue that audience perceptions of public issues are framed by the media discourse. As the "gate keepers," media professionals or the government censors, have the power to decide which facts to include or emphasize, whom to use as sources, 
and what is really at issue in reporting a story. Because frames are built upon underlying structures of beliefs, values, and experiences, disputants often construct frames that differ in significant ways.

In The Art of Framing, Fairhurst and Sarr (1996) write "to hold the frame of a subject is to choose one particular meaning (or set of meanings) over another. When we share our frames with others (the process of framing), we manage meaning because we assert that our interpretations should be taken as real over other possible interpretations" (p. 3). They note that "frames exert their power not only through what they highlight, but what they leave out. In framing, when we create a bias toward one interpretation of our subject, we exclude other aspects, including those that may produce opposite or alternative interpretations" (p. 4). Thus in looking at the Xinwen Lianbo newscast it is important to note not just what is included, but just as importantly what is obviously excluded from the newscast. This gives a clear understanding of how the Chinese government chooses to frame its leaders, China as a whole, and the rest of the world.

In light of this literature review, the following research questions were developed to understand how the outside world, or Block $C$ of the newscast, is framed through the most watched and influential Chinese TV news program Xinwen Lianbo between January 1, 2012 and December 31, 2016.

RQ1: What counties were selected for coverage most often in Xinwen Lianbo's foreign affairs segment?

RQ2: What issues or events were selected for coverage most often in Xinwen Lianbos in its foreign affairs segment?

RQ3: What issues and events were selected for coverage most frequently in respect to the most covered countries?

RQ4: How does Xinwen Lianbo frame the outside world through its foreign affairs news coverage?

\section{Method}

To answer these research questions, a content analysis was conducted of the news coverage of foreign affairs on Xinwen Lianbo from January 1, 2012 to December 31, 2016. The sample used was 2,817 news reports of international stories aired during the 5-year period in Block $\mathrm{C}$ of the newscast. All the news reports were collected from the Xinwen Lianbo Archive (http://tv.cctv.com/lm/ $\mathrm{xwlb} /$ ). Each news story was a coding unit with the main theme of the story and the country featured noted by a coder. For example, Xinwen Lianbo had reported that a "6.5 earthquake hits Northeast India" ("印度东北部发生6.5级地震"). This piece of news was coded as "India" and "Natural Disaster." All the news reports were coded by country or region and by theme. From this thematic analysis of the data twenty-four categories emerged. All the stories were then coded by two coders who are fluent in Chinese and understand the format of Chinese television news. Using the Holsti method of testing intercoder reliability, intercoder agreement on the content of each news report was computed. The reliability measure of the categories of the news stories was .983 . A third coder 
who was not a native Chinese speaker coded a sample of the stories based on the headline describing each story and using Google Translate. A full list of the categories and their descriptions are listed in Appendix.

\section{Results}

As noted previously, foreign news on Xinwen Lianbo occurs in the last third (or Block C) of the newscast. This follows the coverage of China's leaders (Block A) and domestic news (Block B). The data set covering foreign affairs on China Central Television's news bulletin Xinwen Lianbo during the five years under study, allows us to assess what countries were covered the most, what issues were featured in the coverage, what issues were featured in coverage of the top countries, and overall how the most watched and most influential Chinese television news program framed the world outside China to its citizens.

RQ1 asked what countries were covered the most in the foreign affairs segment. During January 1, 2012 to December 31, 2016, the newscast covered events or issues happening in 119 countries. However, 70 percent of the coverage featured only ten countries. Table 1 shows the top ten countries covered most during this period.

Table 1. The Top 10 Countries that Received the Most Coverage during 2012-2016

\begin{tabular}{|l|c|c|}
\hline Country & Occurrences & Percentage \\
\hline The United States & 429 & 15.23 \\
\hline Syria & 351 & 12.46 \\
\hline Japan & 242 & 8.59 \\
\hline Russia & 201 & 7.14 \\
\hline South Korea & 137 & 4.86 \\
\hline Ukraine & 123 & 4.37 \\
\hline Iraq & 112 & 3.98 \\
\hline North Korea & 106 & 3.76 \\
\hline Iran & 105 & 3.73 \\
\hline The United Kingdom & 95 & 3.37 \\
\hline Pakistan & 74 & 2.59 \\
\hline Total & $\mathbf{1 , 9 7 5}$ & $\mathbf{7 0 . 0 7}$ \\
\hline
\end{tabular}

Source: Author's estimations.

As is shown in Table 1, 1,975 foreign affairs stories from ten countries accounted for 70 percent of the total coverage of international affairs on Xinwen Lianbo. The United States was selected for the most coverage with more than 15 percent of the reports in the foreign affairs section of the newscast. The fact that stories pertaining to the United States were selected ahead of other countries frames this country as being very important on the world stage and as being important to China. Following the United States, Syria was the second most covered country with 12.5 percent of the foreign news coverage. This would ordinarily seem unusual, but it is obviously due to the continued war in the country. This is important because war and conflict contributes to an overall frame of turmoil and instability in the world. Images of war stand in stark contrast to the 
images in the rest of the newscast portraying China as a place of peace and prosperity. Other coverage had more to do countries that have close geographic proximity or regional importance to China. For example, Japan, Russia, South Korea, North Korea, and Pakistan. However, there was also considerable coverage of countries who do not share borders with China including Ukraine, Iraq, and Iran. Again the selection of countries appears to do with contributing to an overall theme of the world as an unstable and violent place.

RQ 2 asked about the issues or events that were selected for coverage most often in the Xinwen Lianbo newscast. Table 2 provides a description of the themes in foreign news coverage on Xinwen Lianbo during the five-year period. As seen in Table 2, nearly one fourth of all the news reports selected to be include in the newscast, and dealing with countries outside of China (695 stories), pertain to warfare. Just over 7 percent of the news reports centered on terrorist attacks and terrorism, 6.67 percent on extreme weathers and natural disasters, 4.97 percent on accidents, 4.86 percent on aviation accidents, 4.15 percent on social unrest, 4.15 percent on political scandals, 3.66 percent on international conflicts, and 3.34 percent on nuclear crisis. Appendix 1 outlines each of the themes and their definition.

Table 2. Foreign News Focus on Xinwen Lianbo During 2012-2016

\begin{tabular}{|l|c|c|}
\hline Theme & Occurrences & Percentage \\
\hline Warfare & 695 & 24.67 \\
\hline Political affair & 456 & 16.19 \\
\hline Terrorist attack/terrorism & 203 & 7.21 \\
\hline Accident & 140 & 4.97 \\
\hline Aviation accident & 137 & 4.86 \\
\hline Social unrest & 122 & 4.33 \\
\hline Natural disaster & 138 & 4.90 \\
\hline Political scandal & 117 & 4.15 \\
\hline International conflict & 103 & 3.66 \\
\hline Nuclear crisis & 94 & 3.34 \\
\hline Social affair & 79 & 2.80 \\
\hline Gun violence & 54 & 1.92 \\
\hline Disease & 51 & 1.81 \\
\hline Extreme weather & 50 & 1.77 \\
\hline Refugee crisis & 36 & 1.28 \\
\hline Sports & 35 & 1.24 \\
\hline Economics & 32 & 1.14 \\
\hline Economic crisis & 28 & 0.99 \\
\hline Media scandal & 23 & 0.82 \\
\hline Sports scandal & 22 & 0.78 \\
\hline Other & 18 & 0.64 \\
\hline Crime & 12 & 0.43 \\
\hline Racial conflict & 10 & 0.35 \\
\hline Police violence & 5 & 0.18 \\
\hline Total & $\mathbf{2 6 6 0}$ & $\mathbf{1 0 0}$ \\
\hline
\end{tabular}

There are many issues and events taking place in the world, but it is apparent 
that the issues and events that matter most to Xinwen Lianbo are those that focus on turmoil and chaos. This frames the world as a place that is not safe compared to the stability of China that is featured prominently in the rest of the newscast.

RQ3 asked "What issues and events were selected for coverage most frequently in respect to the most covered countries?" Each country, except for the United States, had a fairly clear focus discernible in the coverage of that country by Xinwen Lianbo. As shown in Table 3, 80 percent of the news coverage of Syria focused on Syrian civil war; similarly, 83 percent of the news coverage of Ukraine reported on its warfare with Russia. Warfare was also the most prominent issue in coverage of Iraq (60.4 percent), Pakistan (39.4 percent) and Russia (30.5 percent). Xinwen Lianbo devoted more stories to disasters/accidents in the United States than in any other region. In reporting of the United States, the primary issues covered were political scandals (18.22 percent), political affairs (11.45 percent), warfare (8.41 percent), and gun violence (7.01 percent).

Table 3. The Most Prominent Issue(s) for the Ten Countries Receiving Most Coverage

\begin{tabular}{|l|c|l|}
\hline Country & Coverage (\%) & Primary issue(s) covered \\
\hline The United States & 15.23 & $\begin{array}{l}\text { Political scandals (18.22\%) } \\
\text { Political affairs (11.45\%) } \\
\text { Warfare (8.41\%) } \\
\text { Gun violence (7.01\%) }\end{array}$ \\
\hline Syria & 12.46 & Warfare (80\%) \\
\hline Japan & 8.59 & Political affairs (52.3\%) \\
\hline Russia & 7.14 & Warfare (30.5\%) \\
\hline South Korea & 4.86 & $\begin{array}{l}\text { International conflicts }(21.9 \%) \\
\text { Political affairs (21.9\%) }\end{array}$ \\
\hline Ukraine & 4.37 & Warfare (83\%) \\
\hline Iraq & 3.98 & Warfare (60.4\%) \\
\hline North Korea & 3.76 & $\begin{array}{l}\text { Political affairs }(40 \%) \\
\text { International conflicts }(23.5 \%)\end{array}$ \\
\hline Iran & 3.73 & Nuclear crisis (50\%) \\
\hline The United Kingdom & 3.37 & $\begin{array}{l}\text { Media scandals (20\%) } \\
\text { Political affairs (13.5\%) }\end{array}$ \\
\hline Pakistan & 2.59 & Warfare (39.4\%) \\
\hline Total & $\mathbf{7 0 . 0 7}$ & \\
\hline
\end{tabular}

RQ4 asks "How does Xinwen Lianbo frame the outside world through its foreign affairs news coverage?" The answer after analyzing the content of stories covering foreign affairs over a five-year period is that the world is framed as unsafe, violent, and chaotic. Even where there is not war, there is crime, disasters, accidents, and social unrest which could potentially lead to war. The Xinwen Lianbo newscast primarily uses ten countries, and a limited set of issues and events, to frame the world as a chaotic, unstable, and unsafe place. As the Chinese audience's window on the world, Xinwen Lianbo shapes its viewers perceptions of the world by framing issues and telling its viewers, many of whom have 
access to little other information, about a world most will never see beyond the screens of a television set. By selectively reporting the outside world in a largely negative tone, China's flagship news bulletin constructs a reality that the world outside China is extremely chaotic, unstable, scary, and dangerous, particularly when compared to the stability and order of their own country. As Table 2 demonstrates, the news angles that cut across various stories on Xinwen Lianbo were limited in scope. For instance, positive stories were rarely addressed, if at all on the news, while problems of warfare and political scandals were widely covered.

\section{Discussion}

Jowett and O'Donnell (2006) state that "whenever a communication source is a monopoly... and the message is consistent and repetitious, people are unlikely to challenge the message" (p. 282). Xinwen Lianbo held the monopoly of its timeslot for decades consistently purposely and systematically focusing on the negative perspective of foreign affairs. The excessive, disproportionate, and repetitive reporting of warfare, terrorism and crimes, and the lack of "feel-good" or positive stories, is a purposeful attempt to frame the world in a negative light and to perpetuate fear among its target audience. References to "warfare" "terrorism" and "crimes" serve as a communication technique to create a negative perception of public order outside China. By covering chaos of international spectacles frequently and prominently, the Chinese audience will regard the world outside China as something to be feared because it was chaotic and dangerous. Conversely the rest of the Xinwen Lianbo newscast meticulously portrays China as a country of order, stability, and the government as an entity that cares for its people. The people in China are portrayed as extremely happy and fulfilled. Even the coverage of the nation's leaders in the first part of the newscast is systematic and orderly with the most important person, the President, featured first followed by news about other officials in order of their rank.

This study lines up with prior research that suggests that exposure to negative news, particularly news replete with disasters, terrorism, crime, and scandals, perpetuates fear among the audience. For example, in terms of the crime news reporting, Chiricos, Eschholz, and Gertz (1997) argue that the fear of crime is in part a by-product of exposure to crime-saturated local television news. Another scholar Altheide (2002) also touched on the relationship between public's perception of fear and news media. He asserted that mass media serve as a tool of social power and social control to create fear among members of society and shape social definitions that govern social action (Altheide, 2002). By framing the news stories in the aforementioned manner, Xinwen Lianbo was able to disseminate an anti-outside world rhetoric to millions of its viewers on a daily basis.

Many smaller and less powerful countries, however, occupied the newscast more frequently than the "known" countries. In a sense, coverage of affairs in the Middle East was significant in the construction of the chaotic and dangerous 
outside world frame. It is true that there is chaos there, but there is also positive news and humanitarian efforts that could be reported on. This may explain why Xinwen Lianbo has a tendency to cover stories in Syria, Ukraine, Iraq, even though these three countries are far away from China. The fact that Xinwen Lianbo devoted more stories to disasters/accidents in the United States than in any other region is a way of demonstrating that this world power has weakness. There is no major conflict within the borders of the United States as in Iraq or Syria. Therefore, the decision to focus on disasters, accidents, and scandals in reporting about the country is another way of framing the country as unsafe and tumultuous.

\section{Conclusion}

As noted earlier white propaganda comes from an identified source, presenting information that is correct, and that portrays the sender as the "good guy." To frame is to lead the audience to draw conclusions that the creator of the content, in this case news reports ordered in a particular way by the newscast producers, desires. The fact that the United States has disasters, both man-made and natural, is true, but it means little unless, as in the case of Xinwen Lianbo, it is part of an overall view of the world as chaotic and unstable. All of the wars, disasters (both man-made and natural), scandals, and crime, stand in stark contrast to the positive and "normal" picture painted of China and its leaders. It is, as Jowett and O'Donnell (2006) note, "Propaganda as journalism...to understand how news management or 'spin' shapes information, emphasizing positive features and downplaying negative ones, casting institutions in a favorable light" (p. 1).

Future research could focus on where young people in China are getting their information from as they are a part of the audience that no longer watches Xinwen Lianbo (Huang, 2014). Is the Chinese government using other media sources to send similar negative messages of the world to young people? Conducting surveys in China is extremely difficult, but it would be interesting to know what people who watch Xinwen Lianbo regularly, particularly those in rural areas with less access to information, think of the world. Also, future research should include clearer descriptions of not just what is being presented to Xinwen Lianbo's audience, but how it is being presented in terms of the complete narrative including images used in the stories and the anchor and reporter text.

George Creel (1941) once wrote, "Propaganda-the fight for the promotion and maintenance of morale-can have no other basis than honesty and candor, for in every human being there is an instinct for truth" (p. 340). He was writing as World War II was unfolding, and in the current case of China the battle is not for morale, but control of the whole being. The Chinese government and the producers of Xinwen Lianbo may argue that portraying the world as a scary and dangerous place is the truth, but it is not the whole truth. One can only speculate how many people viewing Xinwen Lianbo have that instinct for truth and wonder if what they are seeing and hearing is completely true. 


\section{References}

Altheide, D. L. (2002). Creating fear: News and the construction of crisis. Transaction Publishers.

Chang, T. K., \& Chen, Y. (2000). Constructing international spectacle on television: CCTV news and China's window on the world, 1992-1996. In A. Malek \& A. P. Kavoori (Ed.), The global dynamics of news: Studies in international news coverage and news agenda (pp. 197-221). Stamford, CT: Ablex Publishing Corporation.

The global dynamics of news: Studies in international news coverage and news agenda, (2), 197.

Chang, J., \& Ren, H. (2015). Television news as political ritual: Xinwen Lianboand China's journalism reform within the party-state's orbit. Journal of Contemporary China, 25(97), 14-24.

Chang, T., Wang, J., \& Chen, Y. (2002). China's window on the world (1st ed.). Cresskill, NJ: Hampton Press.

China's Xi underscores CPC's leadership in news reporting-Xinhua|English.news.cn. (2016). News.xinhuanet.com. Retrieved from https://ces.to/I9Nd12. [Accessed: 10 May 2017]

Chinese telecom exec calls CCTV news critics low class. (2018). Retrieved from https://ces.to/Cqp1s6. [Accessed: 5 May 2019]

Chiricos, T., Eschholz, S., \& Gertz, M. (1997). Crime, news and fear of crime: Toward an identification of audience effects. Social Problems, 44(3), 342-357.

Cody, E. (2007). In a changing China, news show thrives with timeworn ways. The Washington Post. Retrieved from https://ces.to/Nro9Oz. [Accessed: 3 April 2018]

Creel, G. (1941). Propaganda and Morale. The American Journal of Sociology, 47(3), 340-351.

Entman, R. M. (1993), Framing: Toward Clarification of a Fractured Paradigm. Journal of Communication, 43, 51-58.

Entman, R. M. (2007). Framing Bias: Media in the Distribution of Power. Journal of Communication, 57, 163-173.

Fairhurst, G., \& Sarr, R. (1996). The Art of Framing. San Fransisco: Jossey-Bass Publishers.

Gamson, W., \& Modigliani, A. (1989). Media discourse and public opinion on nuclear power: A constructionist approach. American Journal of Sociology, 95(1), 1-37.

Goffman, E. (1974). Frame analysis: An essay on the organization of experience (1st ed., pp. 21-82). Boston: Harvard University Press.

Huang, C. (2014). Retirement of Xinwen Lianbo anchors prompts calls for overhaul of flagship CCTV news bulletin. South China Morning Post. Available from https:// ces.to/6sOJh5.

Huang, H. (2015). Propaganda as Signaling. Comparative Politics, 47(4), 419-437.

ICAO Annex 13 Appendix. (1994). Iprr.org. Retrieved from https://ces.to/sujhjv. [Accessed: 9 May 2017]

Jowett, G. \& O'Donnell, V. (2006). Propaganda and persuasion. Thousand Oaks, CA.: Sage Publications.

Liu, H. (2009). Probability distribution of dependencies based on a chinese dependency treebank. Journal of Quantitative Linguistics, 16(3), 256-273.

Liu, H., Hudson, R., \& Feng, Z. (2009). Using a Chinese treebank to measure dependency distance. Corpus Linguistics and Linguistic Theory, 5(2), 161-174.

Matthes, J., \& Kohring, M. (2008). The content analysis of media frames: Toward improving reliability and validity. Journal of Communication, 58(2), 258-279. 
McNelly, J., \& Izcaray, F. (1986). International news exposure and images of nations. Journalism \& Mass Communication Quarterly, 63(3), 546-553.

No news is bad news. (2016). The Economist. Retrieved from https://ces.to/GqBOs3.

Olausson, U. (2009). Global warming-global responsibility? Media frames of collective action and scientific certainty. Public Understanding of Science, 18(4), 421-436.

People's Daily. (2014). 央视新闻节目收视高《新闻联播》月收看人次72亿. [online] Media.people.com.cn. Retrieved from https://ces.to/dRWGgy. [Accessed: 11 Nov. 2017]

Pugsley, P., \& Gao, J. (2007). Emerging powers of influence: The rise of the anchor in Chinese television. International Communication Gazette, 69(5), 451-466.

Scheufele, D. (1999), Framing as a theory of media effects. Journal of Communication, 49, 103-122.

Scheufele, D. A., \& Tewksbury, D. (2007). Framing, agenda setting, and priming: the evolution of three media effects models. Journal of Communication, 57: 9-20.

Sterling, C. (2009). Encyclopedia of Journalism (1st ed., pp. 1-236). New York: SAGE Publications.

Sun, W., \& Chio, J. (2012). Mapping media in China (1st ed., p. 105). New York: Routledge.

Szanto, G. (1978). Theater and Propaganda. University of Texas Press.

Terkildsen, N., \& Schnell, F. (1997). How media frames move public opinion: An analysis of the Women's Movement. Political Research Quarterly, 50(4), 879-900.

Tewksbury, D., \& Scheufele, D. A. (2009). News framing theory and research. In J. Bryant, M. B. Oliver (Eds.), Media effects: Advances in theory and research (3rd ed., pp. 17-33). Hillsdale, NJ: Erlbaum.

Tierney, K. (2006). Metaphors matter: Disaster myths, media frames, and their consequences in Hurricane Katrina. The ANNALS of The American Academy of Political and Social Science, 604(1), 57-81.

Tuchman, G. (1978). Making news: A study in the construction of reality. New York: Free Press.

Zhu, Y., \& Berry, C. (2009). TV China. Bloomington, IN: Indiana University Press. 


\section{Appendix}

Accident: Any incident such as traffic accidents (except for an aviation accident), shipwrecks etc.

Aviation accident: According to the International Investigation Standards, an aviation accident refers to "an occurrence associated with the operation of an aircraft which takes place between the time any person boards the aircraft with the intention of flight until such time as all such persons have disembarked" ("ICAO Annex 13 Appendix", 1994). The reason why this category is separated from the "Accident" category is because aviation accidents are rare, but are tragic and high-profile, and therefore have much more social influence.

Crime: Refers to any unlawful act.

Disease: Any story that reports on the cause or effects of disease. For instance, news about the spread of the Ebola virus would be included in this category.

Economic crisis: Refers to a crisis caused by loss of financial assets. The Euro financial crisis is a good example of an economic crisis.

Economics: News events related to banking and economics that are neutrally reported would be labeled "Economics."

Extreme weather: Refers to unpredictable and unusual severe weather, including flooding rain, extreme hot and cold weather.

Gun violence: Violence committed with the use of a deadly weapon.

International conflict: A conflict between different nations or states, involving at least two countries.

Media scandal: Refers to misconduct of media organizations that is detrimental to the public interest. Sexual harassment by prominent media figures, or fabrication of news stories, are included in this category.

Natural disaster: Refers to a natural event that causes great damage or loss of life, such as a flood, earthquake, and hurricane.

Nuclear crisis: Refer to news covering Iran and North Korea's nuclear programs.

Police violence: Refers to excessive force conducted by police officers when handling civilians.

Political affair: Refers to domestic political issues. For instance, News reports such as "Japan Is Moving to Revise Its Pacifist Constitution," "American President Donald Trump fires FBI director James Comey," which deal with political issues in their own country would be considered political affairs. Usually issues related to politics and diplomacy fall into this category.

Political scandal: Refers to misconduct by political agencies or political figures and is considered morally or legally unacceptable.

Racial conflict: Used to describe a conflict between two or more ethnic groups. News stories of Blacks are treated unequally by Whites would be labeled "racial conflict."

Refugee Crisis: Refugees are people from their native country arriving illegally in another country, such as the European Union, to seek asylum.

Social affair: Refers to a social event that is conducted by social group members.

Social unrest: Refers to a large group of people gathering in public to voice demands on issues and fight for those issues. It usually involves rioting. A protest is a typical social unrest.

Sports: Sports news. For example, "Fukushima to Host Baseball in 2020 Tokyo Olympics" is a piece of sports news.

Sports scandal: Refers to disgraceful or discreditable behavior conducted by athletics or sports agencies. Russia's doping scandals and 2015 FIFA corruption case are included in this category. 
Terrorist attack/terrorism: refers to indiscriminate violence conducted by an individual or an organization to attack civilians and create terror or fear in order to achieve a particular goal.

Warfare: Refers to a war or an activity involved in war.

Other: Refers to the news that cannot be put into the above categories. 
